\title{
Structure, Tree Growth and Dynamics of Cedrus atlantica Manetti Forests in Theniet El Had National Park (N-W Algeria)
}

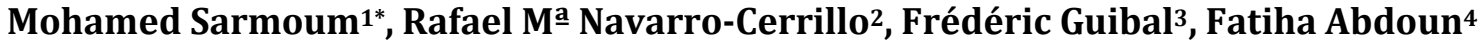 \\ ${ }^{1}$ Laboratory of Plant Physiology and Soil Culture, Faculty of Nature and Life Sciences, Ibn Khaldoun University, Tiaret, Algeria \\ ${ }^{2}$ Department of Forestry Engineering, University of Cordoba, Cordoba, Spain \\ ${ }^{3}$ Mediterranean Institute of Biodiversity and Marine and Continental Ecology (IMBE), Aix-Marseille University (AMU), \\ Aix-en-Provence, France \\ ${ }^{4}$ Laboratory of Plant Ecology and Environment, Faculty of Biological Sciences, University of Science and Technology Houari \\ Boumediene (USTHB), Alger, Algeria \\ Email: *sarmoum_med@yahoo.fr,rmnavarro@uco.es,frederic.guibal@imbe.fr,fatabdoun@yahoo.fr
}

How to cite this paper: Sarmoum, M., Navarro-Cerrillo, R.Ma., Guibal, F. and Abdoun, F. (2018) Structure, Tree Growth and Dynamics of Cedrus atlantica Manetti Forests in Theniet El Had National Park (N-W Algeria). Open Journal of Ecology, 8, 432-446.

https://doi.org/10.4236/oje.2018.88026

Received: July 17, 2018

Accepted: August 27, 2018

Published: August 30, 2018

Copyright $\odot 2018$ by authors and Scientific Research Publishing Inc. This work is licensed under the Creative Commons Attribution International License (CC BY 4.0).

http://creativecommons.org/licenses/by/4.0/

(c) (i) Open Access

\begin{abstract}
In North Africa, Cedrus atlantica forests are in decline, following decades of anthropogenic pressure and repeated drought events. Mixed C. atlantica-Quercus ilex stands located in the Theniet El Had National Park (northwestern Algeria) were considered in the present study. Based on a stratified sampling, six temporary plots were established to describe structure (species composition, density, total height, diameter and basal area) and radial growth in relation to type of stand (pure and mixed), using a dendroecological approach. The diameter distribution of $C$. atlantica indicated the presence of few young individuals and a poor regeneration status in all the stands. The density and basal area of $C$. atlantica were significantly higher in pure stands, which necessitate silvicultural operations. In contrast, $Q$. ilex showed a progressive dynamic, at moderate altitude. Radial growth showed a significant decline from 1980 to the 2000s. The absence of an appropriate management plan and the increase in anthropogenic effects, without ruling out a role for the current climate conditions marked by drought, seem to be the causes of C. atlantica decline.
\end{abstract}

\section{Keywords}

Atlas Cedar, Algeria, Structure, Regeneration, Radial Growth, Forest Management 


\section{Introduction}

The study of the dynamics of forest systems has recently undergone a resurgence of interest, especially in the Mediterranean region where these systems show a tumultuous history of human action and climate change [1]. The distribution areas of European Mediterranean forests have increased, related to the abandonment of agricultural land in recent decades, which has led to the appearance of secondary forests [2]. By contrast, in North Africa, forest degradation has reached alarming levels and has led to the disappearance of endemic and local species and the regeneration of drought-tolerant species [3].

The Atlas cedar (Cedrus atlantica Manetti) is an endemic species of the highest mountains in North Africa (Algeria and Morocco), where it occupies a very fragmented area [4]. This fragmentation is essentially linked to past climatic variations and anthropogenic action [5]. Palynological studies show that the natural range of this species before and during the early Holocene was more extensive than at present [6]. This species is better suited to humid and sub-humid bioclimates and suffers during long and repeated droughts [7].

The Atlas cedar has an important place in the Mediterranean landscape in Algeria and Morocco [8]. Unfortunately, the status of Atlas cedar stands in Algeria indicates a strong degradation linked primarily to anthropogenic action and the unfavorable climatic conditions marked by persistent drought since the 1980s [9] [10]. This situation has led to a loss of vitality and the emergence of tree decline [11] [12]. Additionally, a deficiency of regeneration has been reported for several decades, attributed mainly to anthropogenic action (e.g. grazing) and natural factors-such as erratic seed production, fruit consumption and climatic variability [8] [13]. Because of the high longevity and large size of $C$. atlantica adult trees, their populations remain as dominant components of the forest biomass and architecture for long periods, although functioning demographically as remnant populations which lack significant constant regeneration [8] [14]. The absence of appropriate forest management practices appears to have exacerbated this situation [15]. In this context, the study of the structure and dynamics of the Atlas cedar stands is indispensable for their future management. Research into tree age coupled with analysis of stand structures, land-use history, climatic data and the ecological attributes of different tree species has proven to be a suitable approach for understanding long-term forest dynamics. In Algeria, most studies on the structure of $C$. atlantica forests have focused almost exclusively on how spatial distribution has changed in relation to extrinsic factors, specifically climate or disturbances such as grazing or fire [16] [17] [18]. Additionally, C. atlantica has been widely used in dendrochronology because of its sensitivity to climatic stress and its high longevity [9] [10] [18] [19]. However, no studies on the structural dynamics of $C$. atlantica in relation to dendrochronological dates, addressing temporal changes, have been performed in this country.

Here, we describe and analyze the forest structure, regeneration and recruit- 
ment history of $C$. atlantica stands in the "Theniet El Had" Atlas cedar forest (northwestern Algeria), in pure and mixed forests located along an altitudinal gradient, as a necessary step prior to the development of forest management alternatives to promote forest conservation at the regional scale. The results will improve our understanding of the structure and dynamics of $C$. atlantica forests and allow a management plan to be proposed based on a comprehensive understanding of the structures and regeneration processes.

\section{Material and Methods}

\subsection{Study Area}

The study was conducted in the National Park of Theniet El Had (hereafter TNP), located in the Eastern extension of the Ouarsenis massif (northwestern Algeria) (coordinates $35^{\circ} 47^{\prime} \mathrm{N}$ and $35^{\circ} 54^{\prime} \mathrm{N}, 01^{\circ} 54^{\prime} \mathrm{E}$ and $02^{\circ} 02^{\prime} \mathrm{E}$ ) (Figure 1). The TNP is an area of 3460 ha. It was the first space to be protected in Algeria by the French colonial government, in 1923. After independence, it was re-created as a National Park by the Algerian government, in 1983. Cedar stands cover an area of $1000 \mathrm{ha}$, and they are located mainly on the North slope [20]. Since the 19th century, uncontrolled use of the natural forests (fire, grazing and illegal logging) has led to their gradual degradation [15]. The terrain is a NW-SE slope, with the existence of sandstone formations, reflecting extremely rough topography, especially in the Northern exposures where the slope can exceed 50\%. The altitude

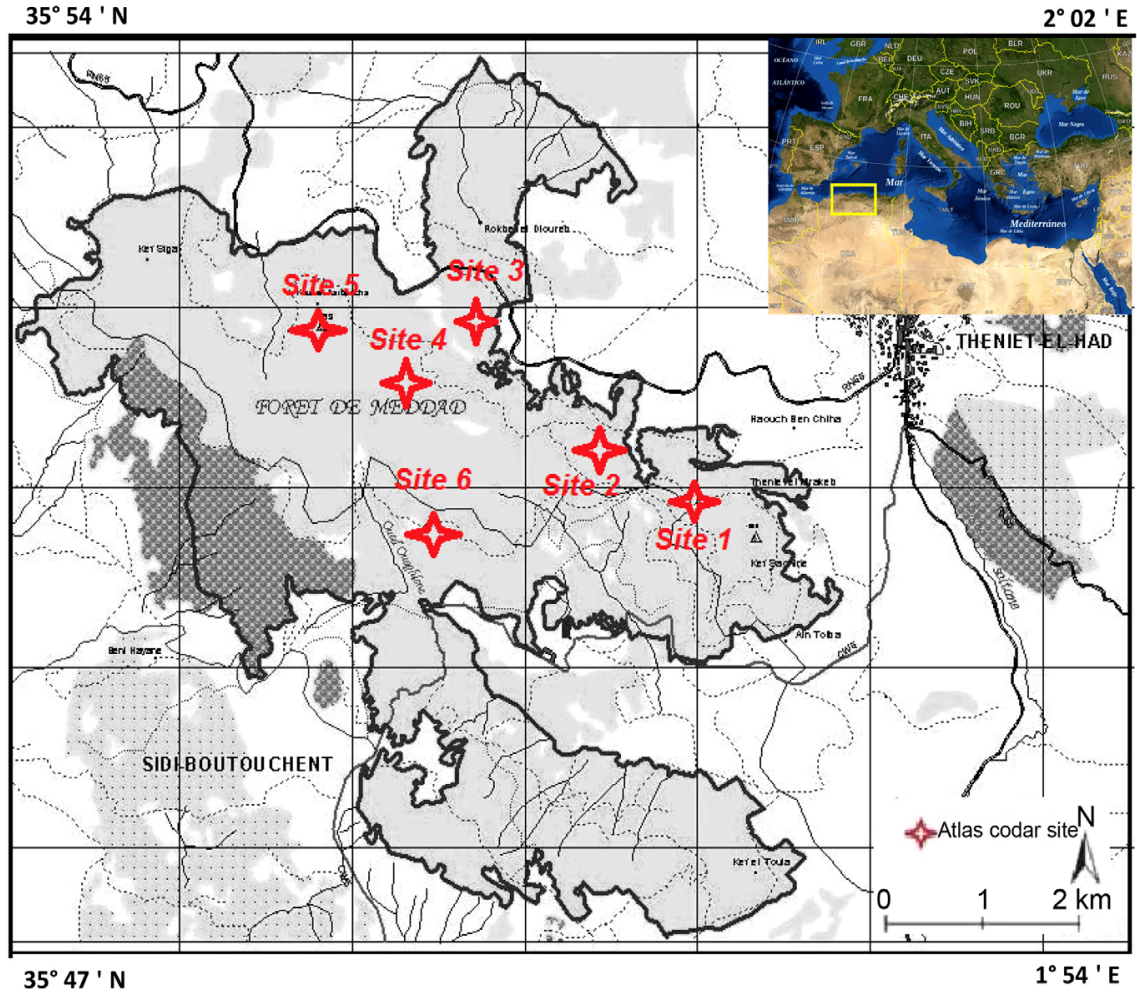

Figure 1. Distribution map of Cedrus atlantica in the National Park of Theniet El Had (North-West Algeria) and the distribution of the sites studied. 
varies between 854 ma.s.l. and 1786 ma.s.l. The geology is characterized by the presence of Oligocene sediments composed of a thick series of sandstones superimposed on thin layers of clay and marl [21]. The dominant soils in the C. atlantica forests are shallow and are sandstone or marl with $\mathrm{pH}=7.3-8.6, \mathrm{C} / \mathrm{N}$ ratio $=4-10$ and low contents of organic matter $\left([\mathrm{C}]=13\right.$ to $\left.81 \mathrm{~kg} \cdot \mathrm{ha}^{-1}\right), \mathrm{N}(3-$ $\left.8.1 \mathrm{~kg} \cdot \mathrm{ha}^{-1}\right)$, phosphorus $\left(\left[\mathrm{P}_{2} \mathrm{O}_{5}\right]=5-71 \mathrm{~kg} \cdot \mathrm{ha}^{-1}\right)$ and potassium $\left(\left[\mathrm{K}_{2} \mathrm{O}\right]=0.35-\right.$ $\left.1.8 \mathrm{~kg} \cdot \mathrm{ha}^{-1}\right)$.

In the TNP, C. atlantica forests occur naturally between 1200 and 1786 ma.s.l. but are rare below $1300 \mathrm{~m}$ due to land-use pressure. The stands included in this study are dominated by $C$. atlantica, often mixed with Quercus ilex L. subsp. ballota (Desf.) Samp and Q. faginea Lam., and, to a lesser extent, Pinus halepensis Mill., Q. suber L. and Juniperus oxycedrus L.

\subsection{Climatic Context}

The climate is characterized by cool, wet winters and hot, dry summers. Annual precipitation varies between $580 \mathrm{~mm}$ (854 ma.s.l.) and $868 \mathrm{~mm}$ (1786 ma.s.l.), with only $5 \%$ falling between June and August, resulting in late-summer drought. The drier period lasts 3 - 4 months, from May to September, giving the study area a Mediterranean climate [22], with the presence of three variants depending on an altitudinal gradient: semi-arid (<1200 ma.s.l.), sub-humid (between 1200 and 1500 ma.s.l.) and humid (>1500 ma.s.l.). Snow cover usually lasts 20 - 30 days between November and March. A trend towards a drier climate has occurred over the past two decades (1980-2002), with a 25\% decrease in annual precipitation [11]. The minimum temperature of the coldest month (January) varies between $-2.2^{\circ} \mathrm{C}$ and $-0.6^{\circ} \mathrm{C}$, and the maximum temperature of the hottest month (July) varies between $27.9^{\circ} \mathrm{C}$ and $32.7^{\circ} \mathrm{C}$.

\subsection{Experimental Design}

Atlas cedar forests in the TNP are spatially heterogeneous and can be classified along an altitudinal gradient. High-altitude stands are characterized by their pure cedar composition and absence of recent human intervention. In medium-altitude forests, the species composition is more complex and human impacts are evident. Although the extent and frequency of logging in these forests are unclear, it is likely that a few moderate, to large-sized trees, have been harvested for local use.

A long this environmental gradient, at each altitude, care was taken to select a plot representative of the site and forest conditions according to the following criteria: 1) at least 10 adult trees were present, 2) the forest patch in which the stand was located was dominated by cedar, 3) reliable information about when the stand was last logged was available, 4) there was no sign of recent disturbance (e.g., fire, windstorm) other than occasional livestock grazing, and 5) it was accessible [14]. Additionally, the selected sites were mapped, and their geographical centers, areas and size were determined (Table 1). In May 2013, six $60 \times$ 
Table 1. Study sites, environmental features and core samples for six Cedrus atlantica populations in the National Park of Theniet El Had (North-West Algeria).

\begin{tabular}{|c|c|c|c|c|c|c|c|}
\hline Sites & Stand types & Coordinates & $\begin{array}{c}\text { Elevation } \\
\text { (m a.s.1.) }\end{array}$ & Exposure & $\begin{array}{c}\text { Slope } \\
(\%)\end{array}$ & Soil type & $\begin{array}{l}\text { Number of } \\
\text { trees (cores) }\end{array}$ \\
\hline Site 1 & Cedrus atlantica & $35^{\circ} 53^{\prime} 23^{\prime \prime} \mathrm{N}-2^{\circ} 00^{\prime} 02^{\prime \prime} \mathrm{E}$ & 1460 & North East & $20-30$ & Verti soil & $15(29)$ \\
\hline Site 2 & Cedrus atlantica & $35^{\circ} 51^{\prime} 44^{\prime \prime} \mathrm{N}-1^{\circ} 59^{\prime} 18^{\prime \prime} \mathrm{E}$ & 1520 & North East & $50-60$ & Colluvial soil & $15(27)$ \\
\hline Site 3 & Cedrus atlantica & $35^{\circ} 51^{\prime} 08^{\prime \prime} \mathrm{N}-1^{\circ} 57^{\prime} 08^{\prime \prime} \mathrm{E}$ & 1700 & North & $50-60$ & Colluvial soil & $15(28)$ \\
\hline Site 4 & $\begin{array}{l}\text { Cedrus atlantica } \\
\text { Quercus ilex } \\
\text { Pinus halepensis }\end{array}$ & $35^{\circ} 52^{\prime} 06^{\prime \prime} \mathrm{N}-1^{\circ} 58^{\prime} 01^{\prime \prime E}$ & 1325 & North East & $10-20$ & Colluvial soil & $15(30)$ \\
\hline Site 5 & $\begin{array}{c}\text { Cedrus atlantica } \\
\text { Quercus faginea } \\
\text { Quercus ilex }\end{array}$ & $35^{\circ} 52^{\prime} 35^{\prime \prime} \mathrm{N}-1^{\circ} 56^{\prime} 00^{\prime \prime} \mathrm{E}$ & 1420 & $\begin{array}{l}\text { North } \\
\text { West }\end{array}$ & $20-30$ & Colluvial soil & $15(30)$ \\
\hline Site 6 & $\begin{array}{c}\text { Cedrus atlantica } \\
\text { Quercus faginea } \\
\text { Quercus suber }\end{array}$ & $35^{\circ} 51^{\prime} 50^{\prime \prime} \mathrm{N}-1^{\circ} 57^{\prime} 27^{\prime \prime} \mathrm{E}$ & 1550 & South West & $50-60$ & Colluvial soil & $15(23)$ \\
\hline
\end{tabular}

$50 \mathrm{~m}$ plots were established in $C$. atlantica stands according to a stratified random design. Forests were classified as a) High altitude and North-facing exposure with pure cedar stands (sites 1,2 and 3), b) Medium altitude with mixed cedar stands (sites 4, 5 and 6).

In each site, all living and dead trees (diameter at breast height, $\mathrm{dbh}>10 \mathrm{~cm}$ ) were identified, and dbh and height $(\mathrm{H})$ were measured using, respectively, a caliper and a hypsometer $(\mathrm{n}=423)$. Regeneration was classified in four size classes: seedlings $(\mathrm{h}<50 \mathrm{~cm})$, short saplings $(50 \mathrm{~cm} \leq \mathrm{h}<130 \mathrm{~cm})$, tall saplings $(\mathrm{h} \geq 130$ $\mathrm{cm}$ and $\mathrm{dbh}<5 \mathrm{~cm})$ and juveniles $(5 \mathrm{~cm} \leq \mathrm{dbh}<10 \mathrm{~cm})$ [14]. For age determination, two cores at breast height per cedar tree with $\mathrm{dbh} \geq 5.0 \mathrm{~cm}(\mathrm{n}=169)$ were extracted using a Suunto ${ }^{\infty}$ increment borer. We added 12 years to the number of years counted at the sampling height to obtain the estimated years of establishment [23]. The age distribution is presented in 10-year intervals.

\subsection{Population Structure Analysis}

We grouped the $C$. atlantica trees into 10 -cm-diameter size classes, averaged densities across sampling plots and generated diameter frequency distributions for each species at each site. To compare the population size structures quantitatively, the Weibull distribution was fitted to each of the empirical dbh probability distributions obtained from the censuses. We fitted two-parameter Weibull functions [24] using the maximum likelihood method.

Prior to the statistical analysis we examined the dbh and stand density for normality and homoscedasticity using the Kolmogorov-Smirnov test and Levene's test, respectively. The square-root transformation of dbh was used to stabilize the variances. Once the basic requirements were found to be met, the stand density of adult trees, dbh, height, stand basal area, and regeneration of $C$. atlantica, $Q$. ilex, and $Q$. faginea were compared between pure and mixed stands 
using analysis of variance (one-way ANOVA) [25]. Null hypotheses were rejected at the $\mathrm{P}<0.05$ level and all analyses, and the results in tables are shown as means with their standard errors for the untransformed variables. All statistical analyses were performed using $\mathrm{R}$, version 3.4.0 [26].

\subsection{Radial Growth Dynamics}

From 15 dominant Atlas cedar individuals per plot, two cores at breast height were taken using a Suunto ${ }^{\oplus}$ increment borer, in a direction parallel to the contour lines, to study radial growth dynamics (Table 1 ). The cores were mounted, sanded and polished; the crossdating was performed under a binocular microscope, following standard dendrochronological methods (Speer 2010). Visual crossdating of samples was conducted before measuring and it was verified using COFECHA after measuring [27]. The ring width was measured to the nearest $0.01 \mathrm{~mm}$ using a LINTAB measuring device and the Time Series Analysis Program (TSAP). A 10-year filtering window was chosen to enhance high-frequency signal and to fit a function to the measured chronologies using the 3pBase program [28]. Two chronologies were created and the trend due to the geometrical constraint of adding a volume of wood to a stem of increasing radius was corrected by converting tree-ring widths into basal area increments (BAI) using the formula $\mathrm{BAI}=\pi\left(R_{t}^{2}-R_{t-1}^{2}\right)$ where $\mathrm{R}$ is the radius of the tree and $\mathrm{t}$ is the year of tree-ring formation using the 3 pBase program [28].

Cumulative growth curves for each series were established to study the effect of environmental conditions on the productivity of each site [29].

\section{Results}

\subsection{Stand Structure}

Among the adult trees, all six plots were dominated by $C$. atlantica (Table 2). The density of $C$. atlantica individuals $(\mathrm{dbh} \geq 5 \mathrm{~cm})$ ranged from 94 (29\% of total tree density) in mixed stands to 203 (76\%) trees ha-lin pure stands and was significantly higher in pure cedar stands than in mixed stands $(\mathrm{F}=7.79, \mathrm{P}=$ 0.049). The densities of $Q$. faginea ranged between $81(25 \%)$ and $16(6 \%)$ trees $\mathrm{ha}^{-1}$ and $Q$. ilex ranged between $21(6 \%)$ and $43(16 \%)$ trees ha ${ }^{-1}$, without significant differences between forest types $(\mathrm{F}=6.63, \mathrm{P}=0.082 ; \mathrm{F}=1.21, \mathrm{P}=0.332$, respectively).

The height of $C$. atlantica differed significantly $(\mathrm{F}=21.81$; $\mathrm{P}<0.01)$ between forest types, where the average value in pure stands was $14 \mathrm{~m}$ and the average value in mixed stands was $11 \mathrm{~m}$. The tree height of $Q$. faginea was comparable but for Q. ilex and J. oxycedrus were smaller than that of cedar; however, these differences were not significant between forest types $(\mathrm{F}=0.04 ; \mathrm{P}=0.84 ; \mathrm{F}=1.63$; $\mathrm{P}=2.70$, respectively).

The mean dbh of $C$. atlantica ranged from $37.5 \mathrm{~cm}$ (mixed stands) to $50.0 \mathrm{~cm}$ (pure stands) (Table 2), differing significantly among sites $(\mathrm{F}=27.48, \mathrm{P}<0.01)$. The mean diameters of $Q$. faginea and $Q$. ilex ranged from $41.6 \mathrm{~cm}$ (mixed 
Table 2. Structural characteristics of the sampling sites in Theniet El Had National Park. Values are means \pm SE. Statistical differences between forest types based on one-way ANOVA are indicated ( $\mathrm{ns}=$ non-significant, ${ }^{*}=\mathrm{P}<0.05$. $\left.{ }^{*}=\mathrm{P}<0.01\right)$.

\begin{tabular}{|c|c|c|c|c|c|c|}
\hline Forest type & Species (\%) & $\begin{array}{l}\text { Adult density } \\
\left(\text { trees } \mathrm{ha}^{-1}\right)\end{array}$ & $\begin{array}{l}\text { Juvenile density } \\
\quad\left(\text { tress } \mathrm{ha}^{-1}\right)\end{array}$ & $\begin{array}{l}\text { Height } \\
\text { (m) }\end{array}$ & $\begin{array}{l}\text { Diameter } \\
(\mathrm{cm})\end{array}$ & $\begin{array}{c}\text { Basal area } \\
\left(\mathrm{m}^{2} \cdot \mathrm{ha}^{-1}\right)\end{array}$ \\
\hline \multirow{4}{*}{ Pure stand } & Cedrus atlantica & $203.3 \pm 15.0^{*}$ & $9.9 \pm 8.3^{\mathrm{ns}}$ & $14.9 \pm 1.2^{\star *}$ & $50.0 \pm 5.1^{\star *}$ & $45.7 \pm 7.2^{*}$ \\
\hline & Quercus faginea & $16.6 \pm 3.3^{\text {ns }}$ & 0 & $10.4 \pm 1.6^{\mathrm{ns}}$ & $36.5 \pm 3.7^{\mathrm{ns}}$ & $1.9 \pm 0.0^{\mathrm{ns}}$ \\
\hline & Quercus ilex & $43.2 \pm 18.5^{\mathrm{ns}}$ & $9.0 \pm 9.0^{\mathrm{ns}}$ & $4.3 \pm 0.2^{\mathrm{ns}}$ & $16.7 \pm 2.0^{\mathrm{ns}}$ & $1.2 \pm 0.6^{\mathrm{ms}}$ \\
\hline & Juniperus oxycedrus & 4.4 & 1.1 & $4.5 \pm 1.3$ & $18.6 \pm 4.2$ & 0.3 \\
\hline \multirow{6}{*}{ Mixed stand } & Cedrus atlantica & $94.4 \pm 35.8$ & $8.8 \pm 4.8$ & $11.7 \pm 2.3$ & $37.5 \pm 10.1$ & $14.3 \pm 4.7$ \\
\hline & Quercus faginea & $81.0 \pm 19.2$ & $3.3 \pm 3.3$ & $11.2 \pm 3.0$ & $41.6 \pm 17.3$ & $9.2 \pm 6.4$ \\
\hline & Quercus ilex & $21.0 \pm 7.7$ & $5.5 \pm 5.5$ & $6.7 \pm 1.8$ & $28.6 \pm 7.0$ & $1.6 \pm 0.6$ \\
\hline & Juniperus oxycedrus & 87.6 & 2.2 & $2.6 \pm 0.1$ & $19.9 \pm 3.5$ & 1.0 \\
\hline & Pinus halepensis & 31.1 & 0 & $9.0 \pm 1.3$ & $34.5 \pm 4.2$ & 3.6 \\
\hline & Quercus suber & 7.7 & 0 & $9.3 \pm 2.1$ & $38.3 \pm 11.2$ & 2.9 \\
\hline
\end{tabular}

stands) to 36.5 (pure stands) $\mathrm{cm}$ and from 28.6 (mixed stands) to 16.7 (pure stands) $\mathrm{cm}$, respectively without significant differences. The basal area of $C$. atlantica ranged from $14.3 \mathrm{~m}^{2} \cdot \mathrm{ha}^{-1}$ (mixed stands) to $45.7 \mathrm{~m}^{2} \cdot \mathrm{ha}^{-1}$ (pure stands, $\mathrm{F}=$ 9.39, $\mathrm{P}=0.03$ ), while those of $Q$. faginea and $Q$. ilex ranged from $9.2 \mathrm{~m}^{2} \cdot \mathrm{ha}^{-1}$ (mixed stands) to $1.9 \mathrm{~m}^{2} \cdot \mathrm{ha}^{-1}$ (pure stands, $\mathrm{F}=0.77, \mathrm{P}=0.44$ ) and from 1.6 $\mathrm{m}^{2} \cdot \mathrm{ha}^{-1}$ (mixed stands) to $1.2 \mathrm{~m}^{2} \cdot \mathrm{ha}^{-1}$ (pure stands, $\mathrm{F}=0.22, \mathrm{P}=0.66$ ), respectively. In pure stands, C. atlantica accounted for over $93 \%$ of the basal area, but in mixed stands less than 57\%. For J. oxycedrus, P. halepensis and Q. suber in mixed stands, the mean basal areas were1, 3.6 and $2.9 \mathrm{~m}^{2} \cdot \mathrm{ha}^{-1}$, respectively.

The distribution of the diameter classes of $C$. atlantica (Figure 2) shows the dominance of trees in the middle classes $(40-50 \mathrm{~cm})$ in pure stands and in low classes $(10-20 \mathrm{~cm})$ in mixed stands type. The dbh size-class Weibull distribution was positively-skewed in form in mixed stands $(c=1.3)$ as result of a peak in abundance for the smallest and intermediate size classes $(<30-40 \mathrm{~cm})$, and a rapid decline in the number of individuals in larger size classes (Figure 2), which indicates that there were abundant young individuals in the stand and that the regeneration status of $C$. atlantica was better in this forest. The Weibull shape statistic indicates that the distributions in pure stands $(c=2.0)$ followed a negative-skewed distribution, meaning few young individuals compared to the individuals of average age and a poor regeneration status. The distribution of the diameter classes of $Q$. faginea and $Q$. ilex showed a high abundance of individuals in the smaller size classes and of intermediate-sized trees $(20<\mathrm{dbh}<40 \mathrm{~cm})$ (data not included). For the other species, the dbh distribution shows the dominance of smaller size classes for $J$. oxycedrus and of intermediate-sized trees for Q. suber and P. halepensis (data not included).

Seedlings, short saplings and tall saplings of $C$. atlantica were very low for both stand types, ranging from 8.8 trees $\mathrm{ha}^{-1}$ (mixed stands) to 9.9 trees $\mathrm{ha}^{-1}$ (pure stands, $\mathrm{F}=0.014, \mathrm{P}=0.931$ ), and they were completely absent in some of the plots (data non-included). The density of juveniles ranged from 3.3 (mixed stands) to 0 trees ha ${ }^{-1}$ (pure stands, $\mathrm{F}=0.60, \mathrm{P}=0.49$ ) for $Q$. faginea, and from 


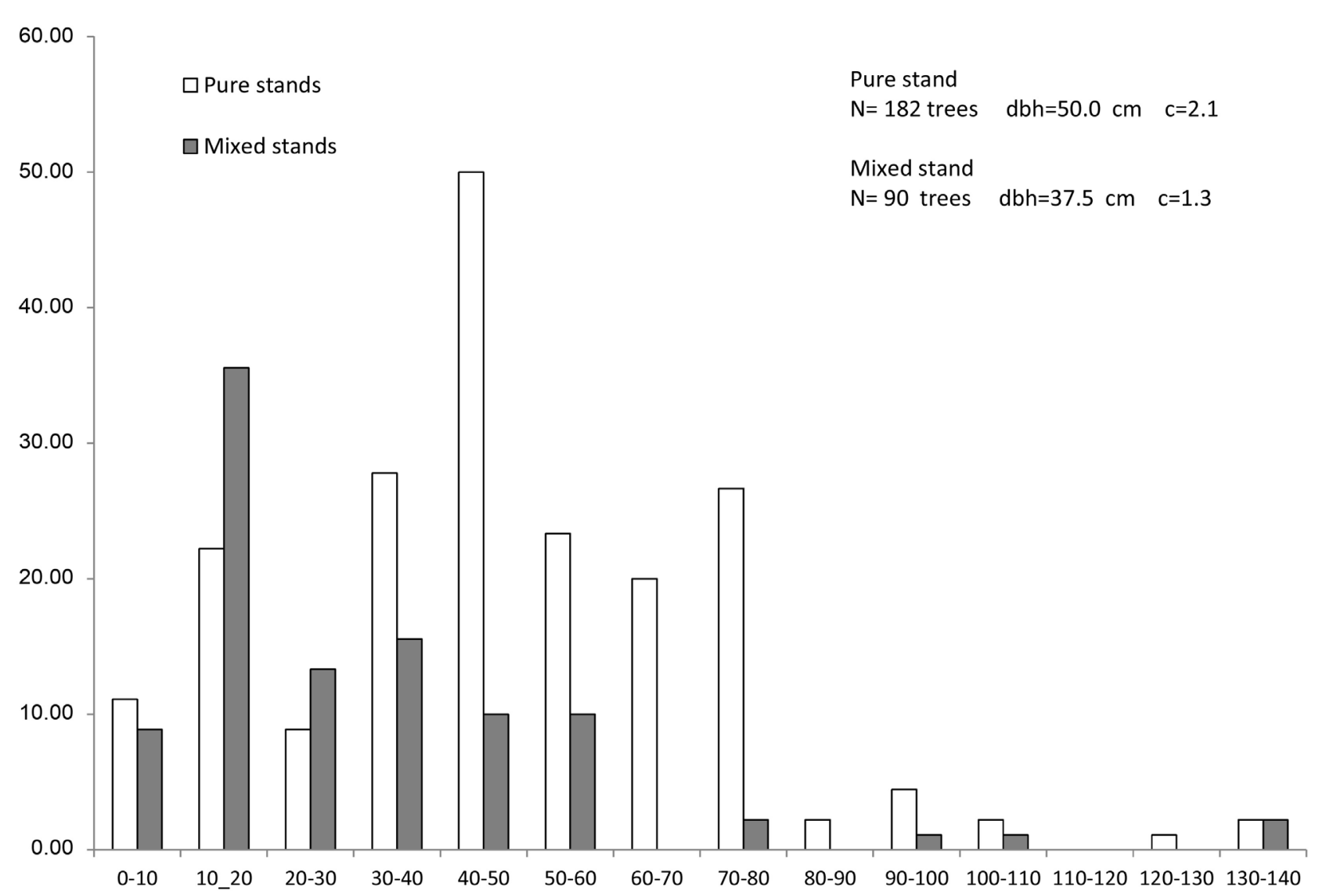

Figure 2. Diameter-class histograms for Cedrus atlantica stands in the National Park of Theniet El Had (North-West Algeria). The $\mathrm{x}$-axis is uniform and covers $10-\mathrm{cm}$ diameter intervals. Sample size $(\mathrm{N})$, mean diameter and standard deviation (x), and Weibull shape statistics (b, c) are also included.

5.5 (mixed stands) to 9.0 trees $\mathrm{ha}^{-1}$ (pure stands, $\mathrm{F}=0.108, \mathrm{P}=0.75$ ) for $Q$. ilex.

\subsection{Cedrus atlantica Colonization and Demography}

The age data from all the samples $(\mathrm{N}=90)$ and the recruitment history at the study site suggest that stands of Atlas cedar are old with a clear dominance three age classes: 100 - 120 years (44.7\%), 120 - 140 years and 140 - 160 years with $21.1 \%$ respectively (Figure 3 ). The oldest tree in the stand was 172 years old, dating from 1838, but most of the aged trees entered the population during the 20th century; only two of the trees cored were more than 160 years old. The percentage of trees less than 100 years old does not exceed $10.5 \%$. The populations exhibited establishment peaks in the 1860-1880s and 1890-1900s (Figure $4)$.

\subsection{Dynamics of Radial Growth}

The curves representing the temporal variations in BAI show the existence of favorable and unfavorable phases for growth (Figure 5). These phases are synchronous for both stands types, suggesting that their origin is common and can be attributed to climatic factors. The stands show a divergence in growth from 


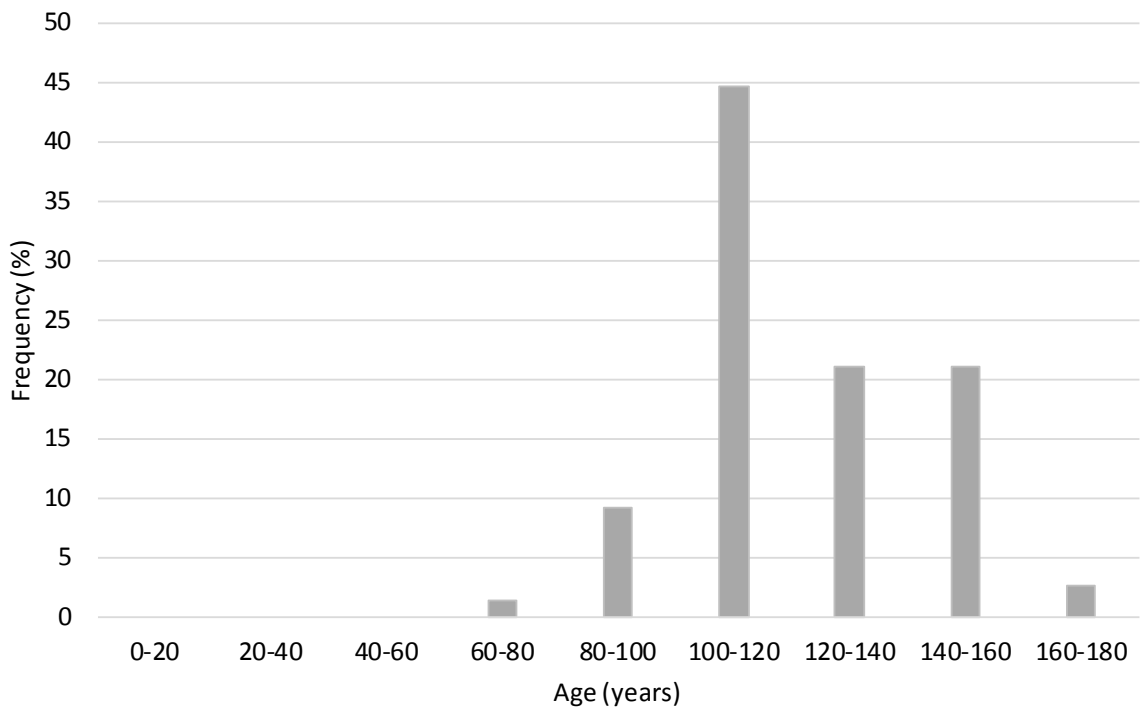

Figure 3. Frequency of $C$. atlantica trees in the National Park of Theniet El Had (North-West Algeria) according to age classes.

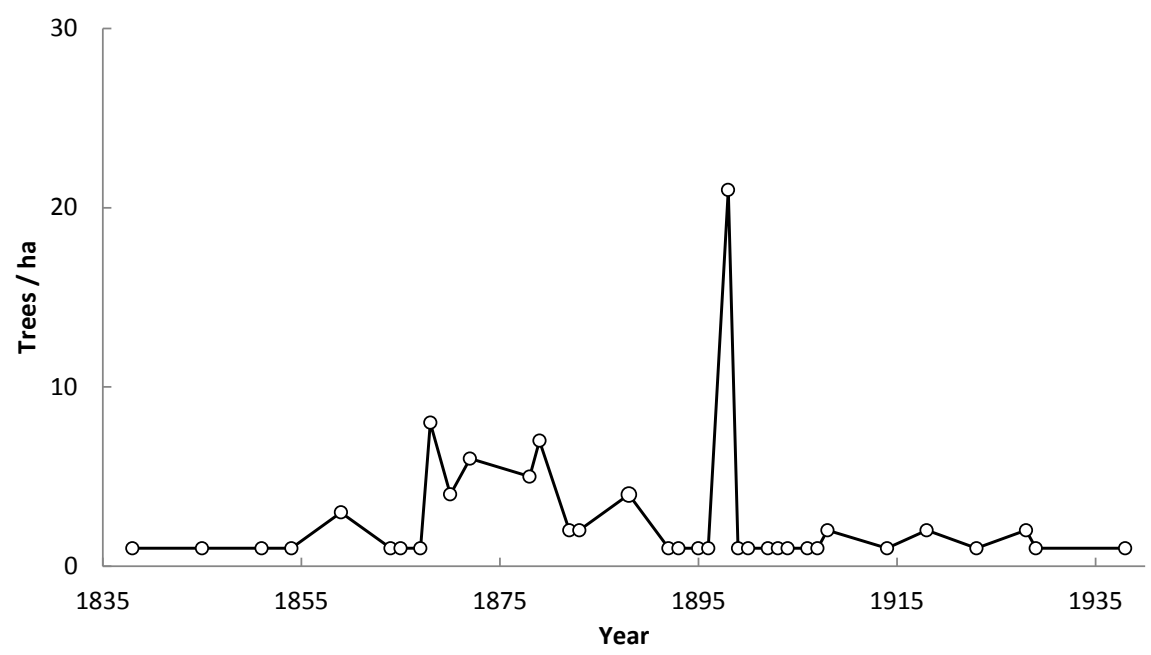

Figure 4. Cedrus atlantica individuals established and still surviving over the past 200 years. The tree recruitment peaks correspond to 1860,1880 and 1900, after the significant mortality phases recorded at the stand.

1910 (Figure 5), the productivity of the pure stand is higher than that of the mixed stand. This situation can be explained by illegal logging in mixed stands that are at low altitude and closer to riparian populations. The land surface curves show a tendency to reduce the land area in both stands during the last three decades; this result can be associated with adverse climatic conditions (drought) and the senescence of stands.

\section{Discussion}

\subsection{Stand Structure}

The current structure of $C$. atlantica stands results from the combined effects of 


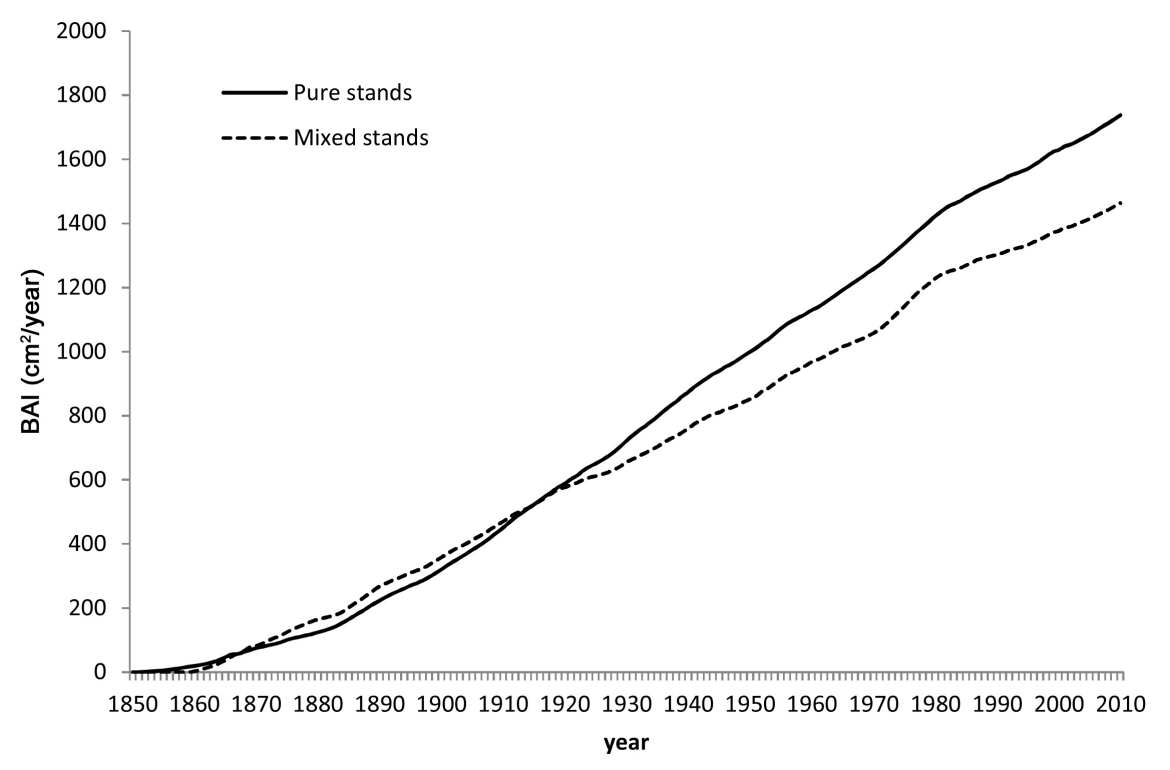

Figure 5. Cumulative basal area increment (BAI) curves of pure and mixed Cedrus atlantica stands in the National Park of Theniet El Had (North-West Algeria).

site characteristics (altitude, aspect, slope and soil), climate and human pressure. Consequently, we can distinguish two types of Atlas cedar stand in the TNP: pure and mixed. The pure $C$. atlantica stands occupy the high altitudes $(>1500 \mathrm{~m}$ a.l.s), where the climatic conditions are more favorable for the species and human activity is moderate. These stands are characterized by high density $(\geq 186.6$ trees $\left.\mathrm{ha}^{-1}\right)$ and low values of basal area $\left(\geq 32.4 \mathrm{~m}^{2} \cdot \mathrm{ha}^{-1}\right)$ which indicate competition between trees. In moderate altitude $(<1500 \mathrm{~m}$ a.s.l), C. atlantica grows in association with $Q$. ilex and, to a lesser degree, with $J$. oxycedrus, $P$. halepensis and $Q$. suber where human activity has been very intense (grazing, fire, opening of forest areas after illicit logging) and the climatic conditions are less favorable, and in association with $Q$. faginea in wet and deep soil [4]. The values of the density $\left(\leq 160\right.$ trees $\left.\mathrm{ha}^{-1}\right)$ and basal area $\left(\leq 25.8 \mathrm{~m}^{2} \cdot \mathrm{ha}^{-1}\right)$ were low. These results are like those found in other cedar forests of Algeria and Morocco [14] [30]. We find the absence of Taxus baccata and Ilex aquifolium in this cedar forest, while the presence of Acer monspessullanum is sporadic. This bears witness to the more-xeric conditions, in comparison to other northern cedar forests [31].

\subsection{Age Structure and Recruitment}

The $C$. atlantica stands are jeopardized by the lack of regeneration and high tree senescence. Juveniles are absent in some sites and their density remains very low in others ( 3.3 to 26.6 trees $\mathrm{ha}^{-1}$ ). The reconstruction of tree recruitment in the TNP has shown peaks linked to climate. Indeed, young cedar recruitment has followed phases of adult tree mortality, especially in the 1860s, 1880s and 1890s, due to drought [32]. This mortality likely created gaps in the stands, allowing young cedars to grow after the establishment of favorable climatic conditions. In this context, [33] noted the existence of an enormous amount of dead wood in 
this forest dating back to the beginning of French colonization (1840) following an anarchic exploitation but from the 1880s the deaths due to drought have amplified the situation.

The role of the climate and the forestry practices during this period are at the origin of the current situation of cedar forest. In 1923, the cedar forest of Theniet El Had was proclaimed a National Park with a total ban on cutting and pasture. This situation would have favored regeneration at first time, but after the closure of the stands and severe drought conditions (during the 1940s) the regeneration process was deteriorated. After the independence of Algeria (1962), the situation did not improve, and the forest continued to undergo all kinds of aggression: illegal cutting, excessive grazing even after its proclamation as a national park in 1983 [20]. Currently, the Atlas cedar forests are the most-important socio-economic factor in the region. Pastoralism, which remains the main activity of the local population, compromises forest regeneration [20]. Additionally, persistent drought since the 1980s [10] [11] may have had a contributing role in the lack of regeneration.

Regeneration problems have been mentioned for all stands of cedar throughout its range in Algeria [13] [15] and Morocco [12] [14] [34]. These authors suggested a set of causes to explain this phenomenon: stand senescence, overgrazing, compaction and soil degradation, drought and the lack of appropriate management.

\subsection{Dynamics of Radial Growth}

The radial growth and the productivity of $C$. atlantica seem to be better in low-density sites with a Northern exposure, high altitude and little slope. This species is very sensitive to fluctuations in climate, especially rainfall [18] [35]. The decrease in radial growth since the 1980s reflects the impact of the drought that has affected the region [19]. This decline was associated with high tree mortality, including the older trees [11] [36]. Future climate scenarios indicate an increase in temperature of $3^{\circ} \mathrm{C}$ by 2100 and a decrease in rainfall of $25 \%$ in North Africa [37], which may compromise the existence of this species in the area.

\subsection{Proposal for the Management of Cedar Forests and Suggestions for New Research}

The current state of $C$. atlantica stands requires the development of a management plan for the short- and medium-term, to improve natural regeneration and reduce tree mortality. This plan must consider the particularities of the environmental conditions of cedar forests and should integrate as much as possible the local populations. Algerian forest policy prescribes a regulatory framework for the management of national parks. Indeed, the TNP is sub-divided into several zones depending on the interests of conservation and the socio-economic equilibrium. The cedar forest is mainly found in the integral zone and benefits 
from a major conservation interest [20]. The application of this policy faces a complex socio-economic situation because local populations use the forest for livestock grazing and to obtain different non-timber products (firewood, resin, etc.). These activities must be moved outside the integral zone to prevent the degradation of the already-fragile cedar forest.

Natural regeneration can be improved through an integrated silvicultural plan. First of all, it will be necessary to apply a thinning program in some stands to reduce density [38]. Once the regeneration is established, seedlings must be protected by reducing grazing [35]. The use of artificial regeneration could be considered in some areas where degradation has reached advanced stages (declining or senescent stands, degraded soils). Direct seeding has already proven successful [8].

\section{Conclusion}

Site history (fire, forest pests and overgrazing) and lack of management have significantly reduced the extent of old-growth $C$. atlantica forests in the Theniet El Had National Park during the past two decades. The results of this study show a clear relationship between structures and dynamics of $C$. atlantica with climate-related mortality events suggesting that structural characteristics of those old-growth woodlands may be threatened under current and projected future conditions. The lack of regeneration has led a reduction in cedar cover and structural complexity. Our analysis suggests that these changes in structure and dynamic together with mortality events may alter the future of $C$. atlantica forests. However, our results are limited by sampling limits as number of locations, recruitment data, or the inclusion of other perturbation events as fires and forest pests. Therefore, more research is still needed concerning the ecological dynamic and biotic and abiotic impacts on $C$. atlantica forests to improve sustainable ecosystem management. In particular, those related to pest and climate change impacts on cedar forest in Argelia may be useful in providing data for ecological studies of the relations between pest outbreaks, stand structure, species diversity, site history (fire, logging, grazing, etc.), and climatic events. We suggest silvicultural and conservative management strategies oriented to maintain and preserve not just the overstory canopies, but also the understory complexity and diversity that supports seedling recruitment, so that the woodland may be sustainable in future climates.

\section{Acknowledgements}

This work was funded through the PNR project (Algerian Ministry of Higher Education and Scientific Research). The authors thank the Algerian Ministry of Agriculture and Directorate General of Forests for the permission to work in the National Park of Theniet El Had. We are very grateful to Abdelkader Masloub (National Park of Theniet El Had, Algeria) for his valuable assistance during fieldwork. We also acknowledge the institutional support of the University of 
Cordoba-Campus de Excelencia CEIA3 and ESPECTRAMED (CGL2017-86161-R) project.

\section{Conflicts of Interest}

The authors declare no conflicts of interest regarding the publication of this paper.

\section{References}

[1] Quézel, P. and Médail, F. (2003) Ecologie et biogéographie des forêts du bassinméditerranéen. Lavoisier, Paris, France, 576.

[2] Chauchard, S., Carcaillet, C. and Guibal, F. (2007) Patterns of Land Use Abandonment, Control Tree Recruitment and Forest Dynamics in Mediterranean Mountains. Ecosystems, 10, 936-948. https://doi.org/10.1007/s10021-007-9065-4

[3] Barbero, M., Bonin, G., Loisel, R. and Quézel, P. (1990) Changes and Disturbances of Forest Ecosystems Caused by Human Activities in the Western Part of the Mediterranean Basin. Vegetatio, 87, 151-173. https://doi.org/10.1007/BF00042952

[4] Benabid, A. (1994) Biogéographie, phytosociologie et phytodynamique des cédraies de l'Atlas Cedrus atlantica (Manetti). Annales de la Recherche Forestière au Maroc, 27, 33-60.

[5] Cheddadi, R., Fady, B., François, L., Hajar, L., Suc, J.P., Huang, K., Demarteau, M., Vendramin, G. and Ortu, E. (2009) Putative Glacial Refugia of Cedrus atlantica Deduced from Quaternary Pollen Records and Modern Genetic Diversity. Journal of Biogeography, 36, 1361-1371. https://doi.org/10.1111/j.1365-2699.2008.02063.x

[6] Magri, D. (2012) Quaternary History of Cedrus in Southern Europe. Annals of Botany-London, 2, 57-66.

[7] Ladjal, M., Huc, R. and Decrey, M. (2005) Drought Effects on Hydraulic Conductivity and Xylem Vulnerability to Embolism in Diverse Species and Provenances of Mediterranean Cedars. Tree Physiology, 25, 1109-1117.

https://doi.org/10.1093/treephys/25.9.1109

[8] M’hirit, O. and Benzyane, M. (2006) Le cèdre de l'Atlas: Mémoire du temps. Mardoga, Hayen, Belgique, 288.

[9] Kherchouche, D., Kalla, M., Gutiérrez, E.M., Attalah, S. and Bouzghaia, M. (2012) Impact of Droughts on Cedrus atlantica Forests Dieback in the Aurès (Algeria). Journal of Life Science, 6, 1262-1269.

[10] Touchan, R., Anchukaitis, K.J., Meko, D.M., Kerchouche, D., Slimani, S., Ilmen, R. and Piermattei, A. (2017) Climate Controls on Tree Growth in the Western Mediterranean. The Holocene, 27, 1429-1442. https://doi.org/10.1177/0959683617693901

[11] Sarmoum, M. (2008) Impact du climat sur le dépérissement du cèdre de l'Atlas. Diagnostic climatique et dendroécologique de la cédraie de Theniet El Had. Master's Thesis, USTHB, Alger, Algérie.

[12] Linares, J.C., Taïqui, L. and Camarero, J.J. (2011) Increasing Drought Sensitivity and Decline of Atlas Cedar (Cedrus atlantica) in the Moroccan Middle Atlas Forests. Forests, 2, 777-796. https://doi.org/10.3390/f2030777

[13] Abdessemed, K.H. (1981) Le cèdre de l'Atlas dans les massifs des Aurès et du Belazma, étude phytosociologiques et problèmes de conservation et d'aménagement. PhD Thesis, Université d'Aix Marseille, Marseille, France.

[14] Navarro-Cerrillo, R.M., Manzanedo, R.D., Bohorque, J., Sánchez-Salguero, R., Sán- 
chez, J., de Miguel, S., Solano, D., Qarro, M., Griffith, D. and Palacios, G. (2013) Structure and Spatio-Temporal Dynamics of Cedar Forests along a Management Gradient in the Middle Atlas, Morocco. Forest Ecology and Management, 289, 341-353. https://doi.org/10.1016/j.foreco.2012.10.011

[15] Messaoudene, M., Rabhi, K., Megdoud, A., Sarmoum, M. and Dahmani-Megrerouche, M. (2013) Etat des lieux et perspectives des cédraiesalgériennes. Forêt Méditerranéenne, 4, 1-8.

[16] Mediouni, K. and Yahi, N. (1989) Etude structurale de la série du cèdre (Cedrus atlantica Manetti) d'AitOuabane (Djurdjura). Forêt Méditerranéenne, 11, 103-112.

[17] Krouchi, F., Derridj, A. and Lefevreb, F. (2004) Year and Tree Effect on Reproductive Organisation of Cedrus atlantica in an Undisturbed Forest. Forest Ecology and Management, 197, 181-189. https://doi.org/10.1016/j.foreco.2004.05.013

[18] Slimani, S., Derridj, A. and Gutiérrez, E. (2014) Ecological Response of Cedrus atlantica to Climate Variability in the Massif of Guetiane (Algeria). Forest Systems, 23, 448-460. https://doi.org/10.5424/fs/2014233-05175

[19] Touchan, R., Anchukaitis, K.J., Meko, D.M., Sabir, M., Attalah, S. and Aloui, A. (2011) Spatiotemporal Drought Variability in Northwestern Africa over the Last Nine Centuries. Climate Dynamics, 37, 237-252. https://doi.org/10.1007/s00382-010-0804-4

[20] Anonymous (2008) Plan de gestion du Parc National de Theniet El Had. Direction générale des forêts. Ministère de l'agriculture et du développement durable, Algérie.

[21] Rivas-Martínez, S., Rivas, S. and Penas, A. (2011) Worldwide Bioclimatic Classification System. Global Geobotany, 1, 1-634.

[22] Mattauer, M. (1958) Etude géologique de l'Ouarsenis oriental (Algérie). Publication de Service des Cartes Géologiques d'Algérie, Algérie, 534.

[23] Guibal, F. (1985) Dendroclimatologie du cèdre de l'Atlas (Cedrus atlantica Manetti) dans le Sud-Est de la France. Ecologia Mediterranea, 11, 87.

[24] Baker, P., Bunyavejchewin, S., Oliver, C. and Ashton, P. (2005) Disturbance History and Historical Stand Dynamics of a Seasonal Tropical Forest in Western Thailand. Ecological Monograph, 75, 317-343. https://doi.org/10.1890/04-0488

[25] Sokal, R.R. and Rohlf, F.J. (1995) Biometry: The Principles and Practice of Statistics in Biological Research. Freeman and Company, New York, USA, 915.

[26] R Core Team (2012) R: A Language and Environment for Statistical Computing. R Foundation for Statistical Computing, Vienna, Austria.

[27] Grissino-Mayer, H.D. (2001) Evaluating Crossdating Accuracy: A Manual and Tutorial for the Computer Program COFECHA. Tree-Ring Research, 57, 205-221.

[28] Guiot, J. and Goeury, C. (1996) PPPBase, a Software for Statistical Analysis of Paleoecological and Paleoclimatological Data. Dendrochronologia, 14, 295-300.

[29] Piovesan, G., Di Filippo, A. and Alessandrini, A. (2005) Structure, Dynamics and Dendroecology of an Old-Growth Fagus Forest in the Apennines. Journal of Vegetation Science, 16, 13-28.

[30] Bentouati, A. and Oujehih, B. (1999) Première étude sur la croissance et la productivité du cèdre de l'Atlas (Cedrus atlantica Manetti) dans le massif de Bélazma (Aurès, Algérie). Forêt Méditerranéenne, 20, 115-119.

[31] Yahi, N. (2007) Etude phytoécologique et phytosociologique et problèmes de conservation des cédraiesalgériennes. PhD Thesis, USTHB, Alger, Algérie.

[32] Touchan, R., Anchukaitis, K.J., Meko, D.M., Attalah, S., Baisan, C. and Aloui, A. (2008) Long Term Context for Recent Drought in Northwestern Africa. Geophysi- 
cal Research Letters, 35, L13705. https://doi.org/10.1029/2008GL034264

[33] Lefebvre, H. (1900) Les forêts de l'Algérie. University of California Library, USA, 458.

[34] Lepoutre, B. (1963) Premier essai de synthèse sur le mécanisme de régénération du cèdre dans le moyen atlas marocain. Annales de la Recherche Forestière au Maroc, 7, 57-163.

[35] Ezzahiri, M. and Belghazi, B. (2000) Synthèse de quelquesrésultats sur la régénération naturelle du cèdre de l'Atlas au Moyen Atlas (Maroc). Sécheresse, 11, 79-84.

[36] Linares, J.C., Taïqui, L., Sangüesa-Barreda, G., Seco, J.I. and Camarero, J.J. (2013) Age-Related Drought Sensitivity of Atlas Cedar (Cedrus atlantica) in the Moroccan Middle Atlas Forests. Dendrochronologia, 31, 88-96.

https://doi.org/10.1016/j.dendro.2012.08.003

[37] IPCC (2007) Climate Change 2007: The Physical Science Basis. Contribution of Working Group I to the Fourth Assessment Report of the Intergovernmental Panel on Climate Change. Cambridge University Press, Cambridge, United Kingdom and New York, NY, USA, 996.

[38] Guillemot, J., Klein, E.K., Davi, H. and Courbet, F. (2015) The Effects of Thinning Intensity and Tree Size on the Growth Response to Annual Climate in Cedrus atlantica: A Linear Mixed Modelling Approach. Annals of Forest Science, 72, 651-663. https://doi.org/10.1007/s13595-015-0464-y 